\title{
Development of a new automatic on-site detector of pesticides in natural waters by photo induced fluorescence, application to three phenylurea and benzoylurea herbicide.
}

\author{
J. P. Bakhoum ${ }^{1,2}$, O. M. A. Mbaye ${ }^{1,2}$ P. A. Diaw ${ }^{1,2,3}$, M. Mbaye ${ }^{1,2}$ L. Cisse $^{1}$, \\ M. D. Gaye-Seye ${ }^{2,4}$ J-J. Aaron ${ }^{4}$, A. Coly ${ }^{2}$, B. Le Jeune ${ }^{2}, \underline{\text { P. Giamarchi }}{ }^{2}$ \\ ${ }^{1}$ Lab. Photochimie et d'Analyse, Univ. C. A. Diop, Dakar, Sénégal \\ ${ }^{2}$ OPTIMAG Lab., Brest Univ., 6 Av. Victor Le Gorgeu, 29285 Brest Cedex, France \\ ${ }^{3}$ Lab. Matériaux, Electrochimie et Photochimie Analytique, Univ. A. Diop, Bambey, Sénégal. \\ ${ }^{4}$ Lab. Géomatériaux et Environnement, Univ. Paris-Est, 77454 Marne-la-Vallée, France \\ *E-mail: philippe.giamarchi@ univ-brest.fr
}

\begin{abstract}
Prototypes of on-site automatic photo induced fluorescence detectors of pesticide in natural waters are set up and applied for the determination of the benzoyl- and phenylurea pesticides, namely fluometuron, monolinuron and diflubenzuron. As these pesticides present no native fluorescence the set up system use the photo conversion under UV irradiation of these pesticides into highly fluorescent photoproducts.

A first system, called AUTOPIF, (evolution the commercial AQUAPOD system) is develop using a detection via a diode array spectrometer. To improve the sensitivity of the method, a second system, called AUTOPIF+, is developed with a more resolute spectrometer and an intensified CCD camera detection.

Analytical applications were carried out in aqueous solution and detected on line with the AUTOPIF and AUTOPIF + system. The calibration curves are linear over one order of magnitude, and the limits of detection are in the $\mu \mathrm{g} \mathrm{mL}^{-1}$ range. The analytical performances of these methods for the determination of the three pesticides are satisfactory in comparison to other classical PIF methods published for the determination of phenylurea pesticides in aqueous solutions. Our results show that the AUTOPIF and AUTOPIF+ methods are versatile, sensible and can be easily applied as an alert system to detect pollutant residues in naturals waters over a threshold value.
\end{abstract}

\section{Introduction}

The importance of pesticides in increasing agricultural yields and crops protection is no longer to be demonstrate. However, they can induce accidental pollution of naturals waters, disrupt aquatic life of many species and also human health due to their persistence and their toxicity. Indeed, many of these pesticides are water soluble and their soil-based residues can remain for several months following application, they can reach foodstuffs and also ground waters ${ }^{[1,2]}$. It becomes so very difficult to escape to the consumption of pesticides. They were real public health problem because cited as responsible to many pathologies such as cancers, neurological, respiratory and reproductive disorders ${ }^{[3,4,5]}$. 
Moreover, the presence of pesticides in ground water will disrupt water treatment plants for drinking water production by contaminating the entire facility and will be difficult to remove from tap water. Consequently, these plants have to be protected permanently by an automatic on-site system from an accidental pollution to detect any concentration over and alert threshold determined by the plant's processing capabilities.

As some pesticides present great photochemical reactivity under UV irradiation, they can be transformed into photoproducts which are detected by fluorescence. It corresponds to the Photo Induced Fluorescent (PIF) methods, which have been developed by numerous authors for the analysis of herbicides ${ }^{[6,7,8]}$, insecticides ${ }^{[9,10,11,12]}$ and others pesticides ${ }^{[13,14,15,16,17]}$. It is worthwhile to note that Diaw et al. ${ }^{[18,19]}$ have determinate fenuron and diflubenzuron, by classical-PIF method using UV irradiation and DL-PIF method with laser irradiation, in Senegalese natural water with satisfactory mean recovery percentage values in the range 95$105 \%$. And, on the other hand, in her previous work, Mbaye et al. applied an on-site automatic detector (namely "AQUAPOD") for the determination of hydrocarbons in aqueous medium by fluorescence detection to monitor pollution of natural waters ${ }^{[20]}$.

In this present work, we have associated these two technics to implement, for the first time, the PIF method on an automatic on-site detector prototype (namely "AUTOPIF") for the continuous monitoring of pesticides in natural waters. Two configurations of the system are studied and compared. Both are using a UV lamp to obtain the photoproducts. The first prototype analyzes their fluorescence on a diode array spectrometer (AUTOPIF); The second prototype use a more resolutive spectrometer and a detection by an ICCD camera (AUTOPIF+) to increase selectivity and sensitivity.

These new systems offer several benefits. Firstly, the PIF method allows to detect non-native fluorescent pesticides. Secondly, using fluorescence measurements instead of absorbance increases the sensitivity and allows a direct of the detection of the pesticides. Thirdly, it avoid the use of complex fluidic system to concentrate the pesticides by solid phase extraction followed by UV detection ("Aquapod SPE50" system ${ }^{[21]}$ ), or the use of HPLC online separation ("SAMOS" system ${ }^{[22]}$ ).

Here, we investigated benzoyl- and phenylureas (BPUs) pesticides due to their intensive application in agriculture, such as systemic herbicides photosynthesis inhibitors fluometuron (FLM) and monolinuron (MLN) ${ }^{[23,24]}$; and diflubenzuron (DFB) a non-systemic insect growth regulator ${ }^{[25]}$. The two systems are then used for the determination of the BPUs pesticides (FLM, MLN and DFB) in natural waters. Analytical performances of these methods were studied and also the analytical applications were carried out in tap and natural waters.

\section{Material and methods}

\subsection{Reagents}

Technical-grade Monolinuron, Fluometuron and Diflubenzuron (Table 1) (purity > 99\%) and spectroscopy solvent Methanol were obtained from Sigma Aldrich (analytical reagent grade). Ultra-pure water (Millipore Mro-MQ System) was used as working solutions. 


\subsection{Materials}

Peristaltic pump (Minipuls), SPE C18 cartridge (LiChrolutRP-18E200mg40-63 mm). $30 \mathrm{~mL}$ quartz flow tubes $(1 \mathrm{~cm}$ diameter). $0.5 \mathrm{~mL}$ cylindrical quartz flow cell. Diode array spectrometer (200-400 nm, Oceans Optics). SpectraPro-550i spectrometer, $f=500 \mathrm{~mm}$ (Acton, MA, USA). CCD intensified Camera (Princeton instruments, NJ, USA). $125 \mathrm{~W} \mathrm{Hg}$ lamp (Philips). $280 \mathrm{~nm}$ UV LED (Thorlabs, France). Commercial "AQUAPOD LIGHT" system (HOCER, instrumentation company, Brest France). Stagraphics 18 Centurion software.

\subsection{Methods}

Stock standard solutions of the pesticides $(310 \mathrm{mg} / \mathrm{L})$ were prepared by dissolving the compounds in methanol. Serial dilutions were performed to obtain the working standard solutions in water. To obtain natural water matrix samples free of organic contamination, traces of organic compounds are eliminated by preparative chromatography using SPE C18 cartridge. The cartridge was preconditioned with $5 \mathrm{~mL}$ of methanol followed by $5 \mathrm{~mL}$ of ultrapure water; $50 \mathrm{~mL}$ of water samples were passed through the cartridge before being spiked.

Table1 : Chemical properties of fluometuron, Monolinuron and diflubenzuron

\begin{tabular}{lllll}
\hline Pesticides & Chemical structure & Formula & $\begin{array}{l}\text { Molecular } \\
\text { weight } \\
\left(\mathrm{g} \mathrm{mol}^{-1}\right)\end{array}$ & $\begin{array}{l}\text { Water } \\
\text { solubility } \\
\left(25^{\circ} \mathrm{C}\right) \\
\left(\mathrm{mg} \mathrm{L}^{-1}\right)\end{array}$ \\
\hline Fluometuron & & 232.2 & 90 \\
\hline Monolinuron & $\mathrm{C}_{10} \mathrm{H}_{11} \mathrm{~F}_{3} \mathrm{~N}_{2} \mathrm{O}$ & 214.5 & 735 \\
\end{tabular}

\section{Development of the experimental setup, results and discussion}

\subsection{Development of the experimental setup}

The two prototypes, AUTOPIF and AUTOPIF+ are developed, to track on-site the presence of non-native fluorescent pesticides in natural waters, by transforming it into PIF compounds after UV irradiation.

Sampling is done by a peristaltic pump and sent through a $25 \mathrm{~mL}$ cylindrical quartz photo reactor flow tube. It is irradiated on the way by a $125 \mathrm{~W} \mathrm{Hg}$ lamp (located at $5 \mathrm{~cm}$ of the tube), to create the PIF compounds. The irradiation time is control by adjusting the flow. The sample is then pumped through a cylindrical detection quartz flow cell $(0.5 \mathrm{~mL})$, and excited at 280 $\mathrm{nm}$ by a UV LED. This wavelength has been chosen because commercial UV LED lower than $280 \mathrm{~nm}$ are still not reliable nowadays for a long period of use. Although this irradiation 
wavelength may not be the most appropriate for all pesticides studied but, it constitute a good compromise.

For AUTOPIF, the fluorescence is collected at $90^{\circ}$ on one side by an optic fiber connected to a spectrometer (Ocean Optics) for the detection (Fig. 1). However, even if the spectrometer has a moderate cost, one of its drawbacks is due to its fixed sweeping zone between 200-400 $\mathrm{nm}$. It will therefore be impossible to detect with the AUTOPIF system the spectra of fluorescents photoproducts with an emission wavelength greater than $400 \mathrm{~nm}$.

For AUTOPIF+, to overcome the limitations of AUTOPIF, on the other side of the flow cell, a second optic fiber sends the fluorescence emission to a more resolute spectrometer (SpectraPro-550i), with a tunable sweeping zone from 200 to $800 \mathrm{~nm}$ (Fig. 1). Then the detection is done by an ICCD camera offering higher sensitivity. AUTOPIF+ is more resolute and more sensitive, but at a higher cost.

The two prototypes are design to be in the future integrated in an autonomous cabinet with a touch screen command interface.

Fig. 1. Description of the experimental systems "AUTOPIF" and "AUTOPIF+"

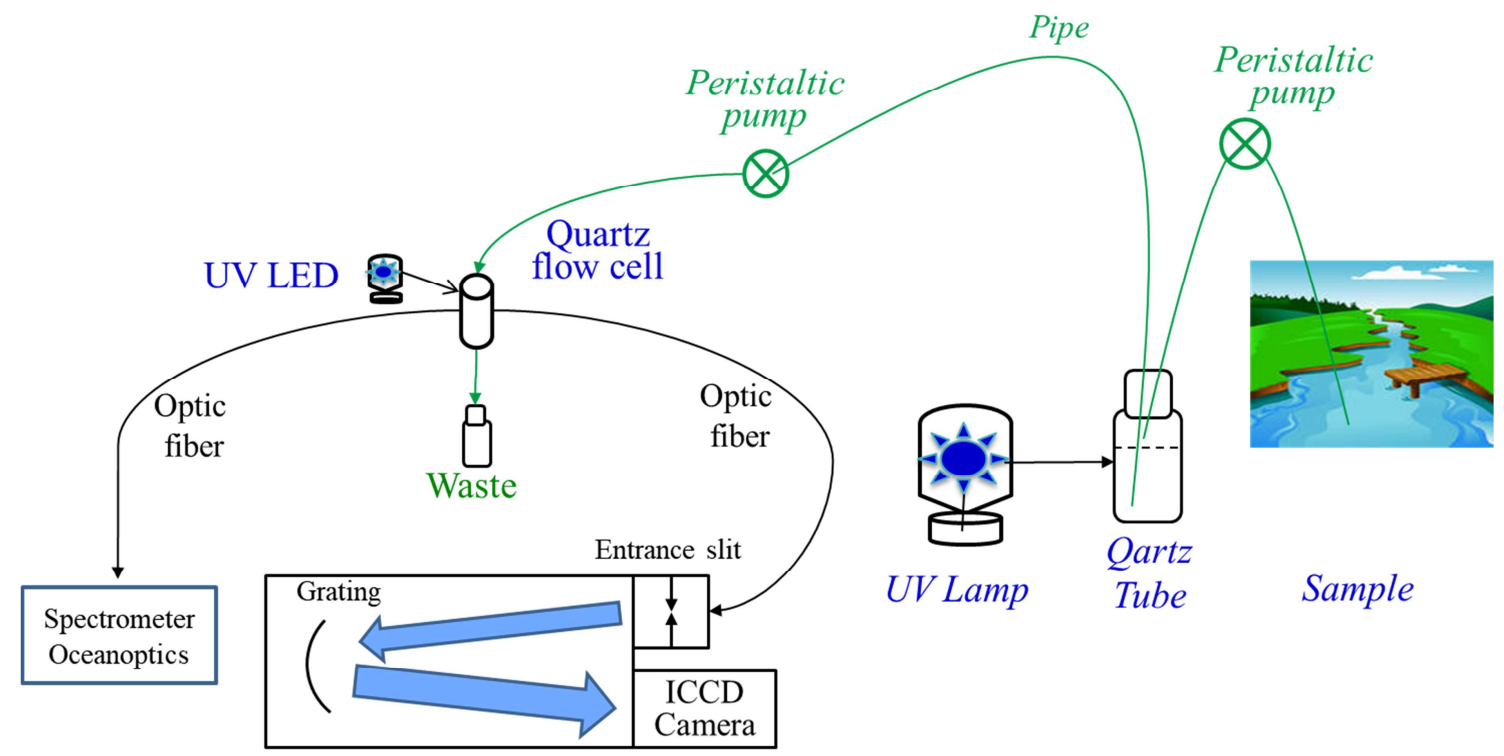

\subsection{Photo-induced fluorescence properties}

MLN, FLM and DFB have a low natural fluorescence while irradiation by UV rays resulted in the formation of highly fluorescent photoproducts. $20 \mathrm{~mL}$ of pesticides aqueous solutions (1.5 $\mu \mathrm{g} . \mathrm{mL}^{-1}$ ) have been pumped throw the system.

One can see that in figure 2, MLN and DFB formed only one PIF compound at $360 \mathrm{~nm}$ and $410 \mathrm{~nm}$ respectively. FLM formed two different PIF compounds at $370 \mathrm{~nm}$ (PIF1) and at $430 \mathrm{~nm}$ (PIF 2). The photo-induced compounds are maximum after $1 \mathrm{~min}$ of irradiation for MLN and FLM-PIF1, after 2 min for DFB and after 3 min for FLM-PIF2 (Figure 3).

All these fluorescence parameters are sum-up in the Table 2. Same photoproduct was detected for DFB by Diaw et al ${ }^{[15]}$ using classical-PIF method in mixture water-methanol (30:70, v/v) at $\mathrm{pH} 4$. 
Fig 2. PIF emission spectra of MLN, FLM and DFB $\left(1.5 \mu \mathrm{g} \cdot \mathrm{mL}^{-1}\right)$ in aqueous medium after one minute of irradiation time and excitation wavelength at $280 \mathrm{~nm}$.

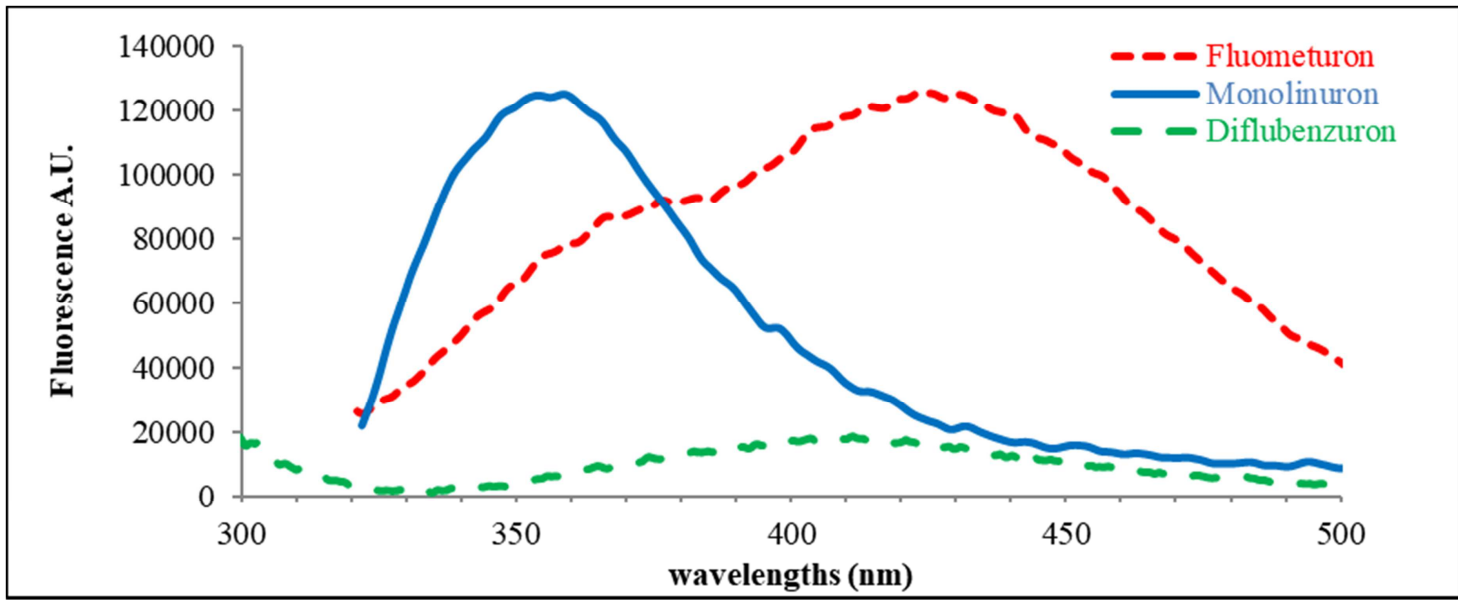

Fig 3. Formation of the photo-induced compounds as a function of the irradiation time.

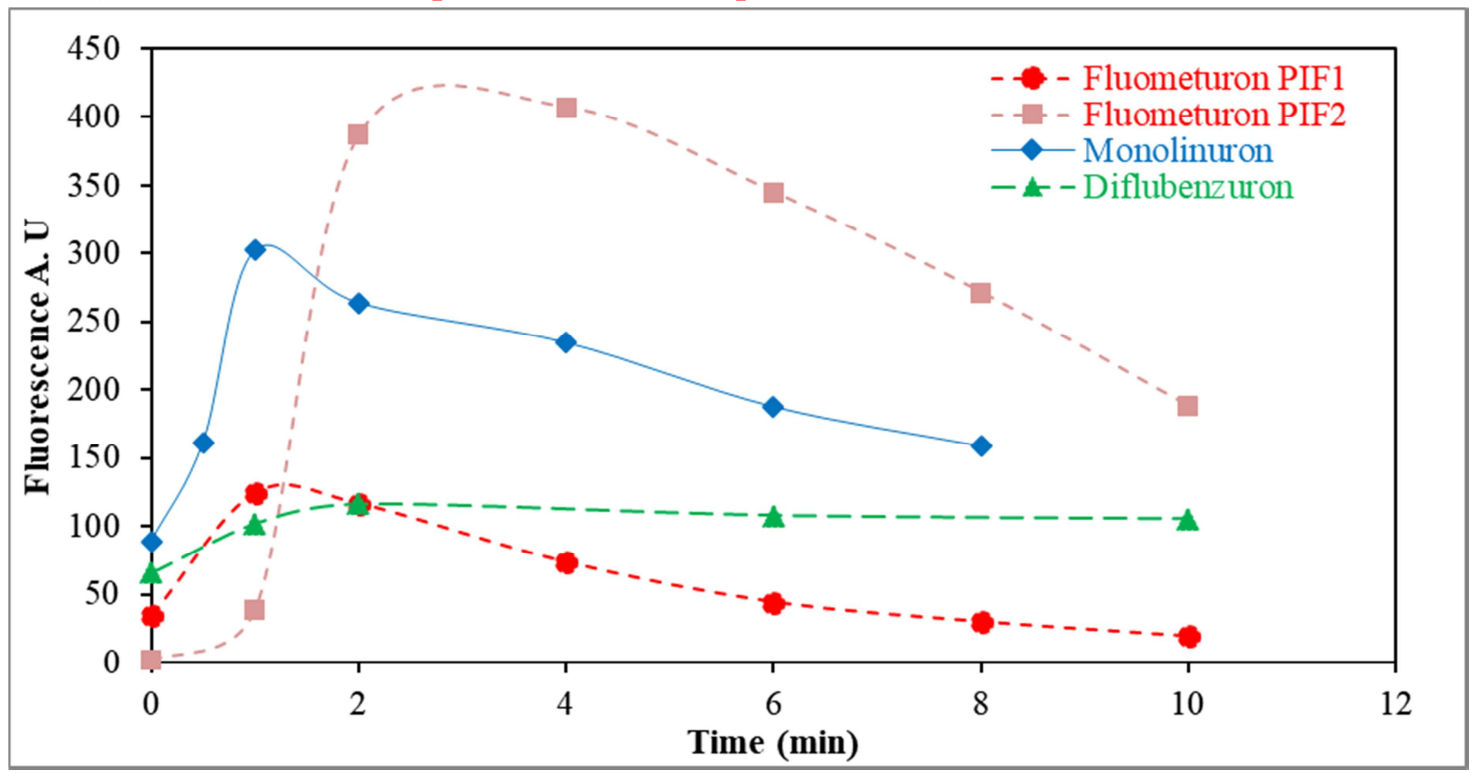

Table 2. Fluorescence spectral properties of the photoproducts of MLN, FLM and DFB $\left(1.5 \mu \mathrm{g} . \mathrm{mL}^{-1}\right)$ in aqueous medium. The more intense bands are in bold characters.

\begin{tabular}{llll}
\hline \multicolumn{1}{c}{ Pesticides } & & $\boldsymbol{\lambda}_{\text {ex }}(\mathbf{n m})$ & $\boldsymbol{\lambda}_{\text {em }}(\mathbf{n m})$ \\
\hline Monolinuron (MLN) & PIF 1 & $\mathbf{2 8 0}$ & $\mathbf{3 6 0}$ \\
\hline Diflubenzuron (DFB) & PIF 1 & $\mathbf{2 2 0} / 330$ & $\mathbf{4 1 0}$ \\
\hline \multirow{2}{*}{ Fluometuron (FLM) } & PIF 1 & $\mathbf{2 4 0}$ & $\mathbf{3 7 0} \ldots \ldots \ldots \ldots \ldots$ \\
& PIF 2 & $\mathbf{2 3 0} / 310$ & $\mathbf{4 3 0}$ \\
\hline
\end{tabular}

\subsection{Method Validation for pesticides determination}

In order to evaluate the analytical usefulness of the method, analytical figures of merit were determined with AUTOPIF and AUTOPIF + (Figure 4). The study was performed with concentration ranges of $0.02-1.5 \mu \mathrm{g} \mathrm{mL}^{-1}$ for MLN, $0.02-2 \mu \mathrm{g} \mathrm{mL}^{-1}$ for FLM and $0.12-1 \mu \mathrm{g}$ $\mathrm{mL}^{-1}$ for DFB. The flow rate was adjusted to obtain an irradiation time of one min in the photo-reactor. This irradiation time was chosen as a compromise between the duration of the 
analysis and the sensitivity, although an irradiation time of 3 min could have given better sensitivity for FLM by studying its PIF2. Calibration curves were constructed by preparing samples in triplicate, containing increasing concentrations of each herbicide. For AUTOPIF, fluorescence intensity has been measured at $360 \mathrm{~nm}$ for MLN, and $370 \mathrm{~nm}$ for FLM-PIF1; as the spectrometer is limited to the wavelength range 200 to $400 \mathrm{~nm}$, DFB cannot be studded. For AUTOPIF+, fluorescence intensity has been measured at $360 \mathrm{~nm}$ for MLN, $410 \mathrm{~nm}$ for DBF and for FLM we have record the emission of the PIF2 at $430 \mathrm{~nm}$ to obtain better sensitivity.

With AUTOPIF, the MLN give the most sensitive result with a slope of 232. 16 AU. mL.mg ${ }^{1}$, while the FLM is less sensitive with a slope of 93.3 AU. mL. $\mathrm{mg}^{-1}$. The calibration of DFB couldn't be realized with AUTOPIF because its photoproduct maximum emission wavelength is over $400 \mathrm{~nm}$ and therefore cannot be detected. With AUTOPIF+, the MLN give also the most sensitive result with a slope of 89116 AU. mL.mg ${ }^{-1}$, while FLM and DFB are less sensitive, with a slope of 52832 AU. mL.mg ${ }^{-1}$ and 16221 AU. mL.mg ${ }^{-1}$ respectively.

The linearity of the calibration curve was evaluated by a variance analysis (table 3 ) for the three pesticides. The regression variance $\left(\mathrm{V}_{\mathrm{REG}}\right)$ is in all cases significantly higher than the residual variance $\left(\mathrm{V}_{\mathrm{RES}}\right)$ ( $p$-value $\left.\leq 5 \%\right)$, meaning that the regression is significant. Moreover, the lack of fit variance is not significantly higher than the pure error variance ( $p$-value $>5 \%)$ meaning that the linear model is validated. A Student $t$ test has shown that the intercepts of calibration curves are not significantly different from zero ( $p$-value $>5 \%$, ) for the three pesticides except the FLM for AQUAPIF+ which has p-value close to 3.3\% (Table 4).

Measurements have been conducted using the AUTOPIF and AUTOPIF + methods at the same time, on the same samples, to compare their results. With the AUTOPIF+ method we obtained detection limits 1.9, 5.2 and 17.4 ng. $\mathrm{mL}^{-1}$ for MLN, FLM and DFB respectively which are lower with those obtained with the AUTOPIF method i.e.: 3.01 and 12.02 ng. $\mathrm{mL}^{-1}$ ng.mL ${ }^{-1}$ for MLN and FLM; showing that AUTOPIF+ is more sensitive.

Moreover, the higher sensitivity obtains for MLN, for both AUTOPIF and AUTOPIF+, is also due to a better adequacy of the LED excitation wavelength $(280 \mathrm{~nm})$ to its optimal excitation wavelength $(280 \mathrm{~nm})$ compared to theses of DBF and FLM (i.e.: 220/330 nm; $240 \mathrm{~nm}$; Table2).

Table 5 compares our results to some other on-site or laboratory methods for pesticide analysis, using UV detection or PIF. It sums up experimental protocols, analytical performances, advantages and drawbacks. We can note that AUTOPIF and AUTOPIF+ onsite systems give LOD values similar to the lowest of the literature obtained by laboratory systems without SPE pre-concentration; which indicates a good sensitivity. It should be noted that, compares to other method AUTOPIF and AUTOPIF+ are easy to implement, with a short analysis time and do not requires organic solvents. 
Table. 3: Evaluation parameters of the linear functions of the AUTOPIF and AUTOPIF+ method by variance analysis at a confidence level of $5 \%$.

\begin{tabular}{|c|c|c|c|c|c|c|}
\hline & & \multicolumn{2}{|l|}{ AUTOPIF } & \multicolumn{3}{|l|}{ AUTOPIF+ } \\
\hline & & MLN & FLM & MLN & FLM & DFB \\
\hline \multirow{3}{*}{ ANOVA 1} & $\mathrm{~V}_{\mathrm{REG}}$ & $2.27610^{5}$ & $6.48110^{4}$ & $2.84010^{10}$ & $2.24210^{10}$ & $4.29910^{8}$ \\
\hline & $\mathrm{V}_{\mathrm{RES}}$ & 702.295 & 74.530 & $2.74810^{7}$ & $4.41810^{6}$ & $2.80610^{5}$ \\
\hline & $P$ value & 0.0000 & 0.0000 & 0.0000 & 0.0000 & 0.0000 \\
\hline \multirow{3}{*}{ ANOVA 2} & $\mathrm{~V}_{\mathrm{LOF}}$ & 254.425 & 115.713 & $2.47710^{7}$ & $2.32210^{6}$ & $13.55210^{5}$ \\
\hline & $\mathrm{V}_{\mathrm{PE}}$ & 836.657 & 62.175 & $2.82910^{7}$ & $5.18010^{6}$ & $3.324 \quad 10^{5}$ \\
\hline & $P$ value & 0.821 & 0.200 & 0.485 & 0.771 & 0.835 \\
\hline
\end{tabular}

Table 4: Analytical figures of merit of the three pesticides and performances of AUTOPIF and AUTOPIF+ methods.

\begin{tabular}{|c|c|c|c|c|c|}
\hline \multicolumn{3}{|c|}{ AUTOPIF } & \multicolumn{3}{|c|}{ AUTOPIF+ } \\
\hline & MLN & FLM & MLN & FLM & DFB \\
\hline Slope & $2.3210^{2}$ & 93.30 & $8.2010^{4}$ & $5.3310^{4}$ & $1.6210^{4}$ \\
\hline Intercept & 1.85 & 7.13 & $1.3410^{3}$ & $1.8510^{3}$ & $3.8710^{2}$ \\
\hline $\mathrm{STD}^{\mathrm{a}}$ & 11.021 & 3.288 & $2.1810^{3}$ & $7.8810^{2}$ & $2.4310^{2}$ \\
\hline$P$ value & 0.869 & 0.049 & 0.549 & 0.033 & 0.128 \\
\hline $\mathrm{LOD}\left(\mathrm{ng} \cdot \mathrm{mL}^{-1}\right)^{\mathrm{b}}$ & 3.09 & 12.02 & 1.98 & 5.25 & 17.47 \\
\hline LOQ (ng. $\left.\mathrm{mL}^{-1}\right)^{\mathrm{c}}$ & 10.29 & 37.08 & 8.49 & 16.75 & 55.42 \\
\hline LOD $\left(\mathrm{mol}^{-L^{-1}}\right)^{\mathrm{b}}$ & $1410^{-9}$ & $4610^{-9}$ & $810^{-9}$ & $2210^{-9}$ & $5610^{-9}$ \\
\hline LOQ $\left(\mathrm{mol} . \mathrm{L}^{-1}\right)^{\mathrm{c}}$ & $5110^{-9}$ & $15510^{-9}$ & $2510^{-9}$ & $6910^{-9}$ & $16910^{-9}$ \\
\hline
\end{tabular}

${ }^{a}$ standard deviation of the intercept; ${ }^{b}$ LOD: limit of detection, defined as the concentration of analyte giving a signal-to-noise $(\mathrm{S} / \mathrm{N})$ ratio of $3 ;{ }^{\mathrm{c}}$ LOQ: limit of quantification, defined as the concentration of analyte giving a signal-to-noise $(\mathrm{S} / \mathrm{N})$ ratio of 10 . 
Table 5. Comparison of the analytical performances, protocols, advantages and drawbacks of some on-site systems and laboratory systems.

\begin{tabular}{|c|c|c|c|c|c|c|c|c|}
\hline Pesticides & Method & Protocol & \begin{tabular}{|c|}
$\left.\mathbf{L O D} L^{-1}\right)$ \\
$(\mathrm{ng}$
\end{tabular} & \begin{tabular}{|c}
$\mathbf{L Q}$ \\
$\left(\mathrm{ng} \mathrm{mL}^{-1}\right)$
\end{tabular} & Sample & Advantages & Drawbacks & Ref. \\
\hline $\begin{array}{l}\text { MLN } \\
\text { FLM } \\
\text { DFB }\end{array}$ & $\begin{array}{l}\text { On-site: } \\
\text { "AUTOPIF" } \\
\text { "AUTOPIF+" }\end{array}$ & $\begin{array}{l}\text { PIF method implemented on a new } \\
\text { automatic on-site detector in water without } \\
\text { SPE pre-concentration. }\end{array}$ & \begin{tabular}{|l|}
$1.9-$ \\
12.0
\end{tabular} & $\begin{array}{l}5.9- \\
36.0\end{array}$ & $\begin{array}{l}\text { - River water, } \\
\text { - Tap water, } \\
\text { - Sea water }\end{array}$ & $\begin{array}{l}\text { - On-site system; } \\
\text { - Continuous } \\
\text { screening of } \\
\text { pesticides. } \\
\text { - Short analysis } \\
\text { time. } \\
\text { - Do not require } \\
\text { organic solvents. }\end{array}$ & & $\begin{array}{l}\text { This } \\
\text { work }\end{array}$ \\
\hline $\begin{array}{l}\text { Atrazine } \\
\text { Isoproturon } \\
\text { Diuron }\end{array}$ & $\begin{array}{l}\text { On-site: } \\
\text { "Aquapod } \\
\text { SPE50" }\end{array}$ & $\begin{array}{l}\text { SPE pre-concentration } \\
\text { UV detection }\end{array}$ & $\begin{array}{l}0.9- \\
1.5\end{array}$ & - & River water & $\begin{array}{l}\text { - On-site system. } \\
\text { - Continuous } \\
\text { screening of } \\
\text { pesticides. }\end{array}$ & $\begin{array}{l}\text { - Complex fluidic system } \\
\text { - Need frequent } \\
\text { maintenance. }\end{array}$ & {$[21]$} \\
\hline $\begin{array}{l}\text { Simazine } \\
\text { Chloroluron } \\
\text { Atrazine } \\
\text { Isoproturon }\end{array}$ & $\begin{array}{l}\text { On-site: } \\
\text { "SAMOS" }\end{array}$ & $\begin{array}{l}\text { SPE pre-concentration } \\
\text { HPLC separation } \\
\text { UV detection }\end{array}$ & $0.6-1$ & - & River water & Selectivity & $\begin{array}{l}\text { - Complex for an on-site } \\
\text { system. } \\
\text { - Need frequent } \\
\text { maintenance. }\end{array}$ & {$[22]$} \\
\hline Dichlorprop & $\begin{array}{l}\text { Laboratory: } \\
\text { PIF- } \\
\text { Photooxydation }\end{array}$ & $\begin{array}{l}\text { Photochemically induced fluorescence } \\
\text { detection, correlated with the mechanism of } \\
\text { photoxidation. } \\
50 \%(\mathrm{v} / \mathrm{v}) \text { methanol and } \mathrm{pH} 5 \text { buffer } \\
\text { solutions }\end{array}$ & 0.8 & - & $\begin{array}{l}\text { - Tomato; } \\
\text { - Fruits (straw } \\
\text { berry tree berry, } \\
\text { orange, plum). }\end{array}$ & Sensitive & Longer irradiation time. & {$[26]$} \\
\hline DFB & $\begin{array}{l}\text { Laboratory: } \\
\text { SPE-HPLC- } \\
\text { PIF }\end{array}$ & $\begin{array}{l}\text { On-line pre-concentration method. } \\
\text { Fluorescence detection after photochemical } \\
\text { induced fluorescence (PIF) postcolumn } \\
\text { derivatization. }\end{array}$ & 10 & 40 & Ground water & $\begin{array}{l}\text { Reduce the } \\
\text { problem of } \\
\text { interference }\end{array}$ & $\begin{array}{l}\text { - Use of a lot of organic } \\
\text { solvent; } \\
\text { - Need complex pre- } \\
\text { concentration steps. }\end{array}$ & [27] \\
\hline
\end{tabular}




\begin{tabular}{|c|c|c|c|c|c|c|c|c|}
\hline $\begin{array}{l}\text { Fenuron } \\
\text { DFB }\end{array}$ & $\begin{array}{l}\text { Laboratory: } \\
\text { DL-PIF }\end{array}$ & $\begin{array}{l}\text { Laser to obtain the photoproduct(s) and to } \\
\text { simultaneously analyse their fluorescence. } \\
\text { Short acquisition time on I CCD camera. } \\
\text { Water and 50/50(v/v) methanol-water }\end{array}$ & $\begin{array}{l}1.5- \\
4.8\end{array}$ & $5-16$ & $\begin{array}{l}\text { - River water } \\
\text { - Sea water }\end{array}$ & Sensitivity & $\begin{array}{l}\text { Need a compromise } \\
\text { between: } \\
\text { - The laser wavelength, } \\
\text { - The maximal absorption } \\
\text { wavelength; } \\
\text { - The optimal excitation } \\
\text { wavelength. }\end{array}$ & [19] \\
\hline $\begin{array}{l}\text { Carboxin } \\
\text { Monalide } \\
\text { Propanil }\end{array}$ & $\begin{array}{l}\text { Laboratory: } \\
\text { HPLC-DL-PIF }\end{array}$ & $\begin{array}{l}\text { On-line coupling of DL-PIF with liquid } \\
\text { chromatography } 60: 40(\mathrm{v}: \mathrm{v}) \text { methanol- } \\
\text { water. }\end{array}$ & $\begin{array}{l}0.53- \\
3.64\end{array}$ & $\begin{array}{l}1.77- \\
12.14\end{array}$ & $\begin{array}{l}\text { - River water } \\
\text { - Sea water }\end{array}$ & $\begin{array}{l}\text { - Reduce the } \\
\text { problem of } \\
\text { interference; } \\
\text { - Improve the } \\
\text { selectivity }\end{array}$ & $\begin{array}{l}\text { Need a compromise } \\
\text { between: } \\
\text { - The laser wavelength, } \\
\text { - The maximal absorption } \\
\text { wavelength; } \\
\text { - The optimal excitation } \\
\text { wavelength. }\end{array}$ & {$[28]$} \\
\hline $\begin{array}{l}\text { Isoproturon } \\
\text { Néburon, } \\
\text { Linuron, } \\
\text { Diuron }\end{array}$ & $\begin{array}{l}\text { Laboratory: } \\
\text { FIA-MEPIF }\end{array}$ & $\begin{array}{l}\text { Flow injection analysis. } \\
\text { Micellar-enhanced photochemically } \\
\text { induced fluorescence in buffered aqueous. }\end{array}$ & $\begin{array}{l}330- \\
920\end{array}$ & - & Tap water & & $\begin{array}{l}\text { Impossible to determine the } \\
\text { maximum amount of } \\
\text { photoinduced compounds }\end{array}$ & [29] \\
\hline Isoproturon & $\begin{array}{l}\text { Laboratory: } \\
\text { SPE-HPLC- } \\
\text { PIF }\end{array}$ & $\begin{array}{l}\text { SPE pre-concentration. } \\
\text { HPLC separation acetonitrile / buffer 60:40 } \\
(\mathrm{v} / \mathrm{v})(\mathrm{pH} 7,0.01 \mathrm{M}) \text {. } \\
\text { PIF derivatization. } \\
\text { Fluorescence detection. }\end{array}$ & $\begin{array}{l}160- \\
800\end{array}$ & - & River water & $\begin{array}{l}\text { Reduce } \\
\text { interference } \\
\text { problems }\end{array}$ & The time analysis is long & [7] \\
\hline Lufenuron & $\begin{array}{l}\text { Laboratory: } \\
\text { PIF }\end{array}$ & $\begin{array}{l}\text { Photo Induced Fluorescnce. } \\
\text { Performed in several media: methanol, } \\
\text { ethanol and 2propanol }\end{array}$ & 22 & - & River water & $\begin{array}{l}\text { Easy to } \\
\text { implement }\end{array}$ & $\begin{array}{l}\text { Time not defined in water } \\
\text { and less sensitive than our } \\
\text { method }\end{array}$ & {$[30]$} \\
\hline
\end{tabular}


Fig. 4. Calibration curves of MLN, FLM and DFB, (excitation at $280 \mathrm{~nm}$ UV LED, PIF fluorescence detection at $360 \mathrm{~nm}$ for MLN, $370 \mathrm{~nm}$ for FLM-PF1(AUTOPIF) and $430 \mathrm{~nm}$ for FLM-PIF2 (AUTOPIF+), and $410 \mathrm{~nm}$ for DFB).
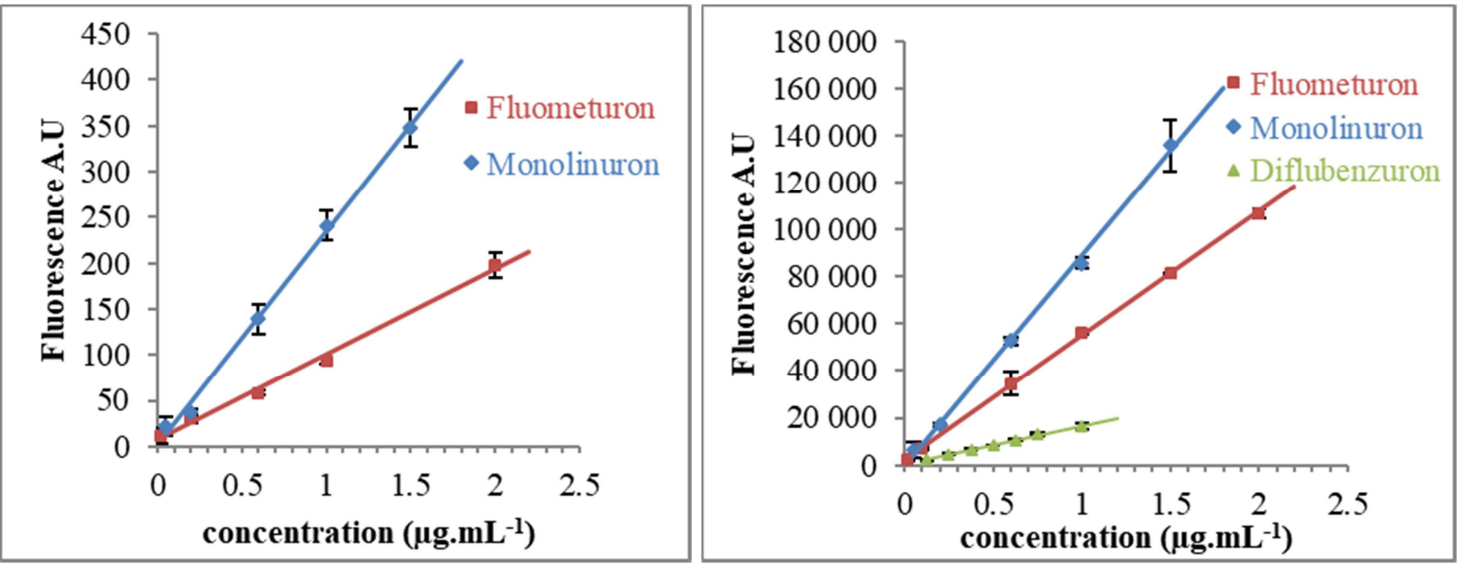

\subsection{Analytical applications}

The usefulness of the method was tested with recovery studies carried out in different natural samples. From Senegal, we have taken samples from Senegal River which irrigates one of the most important agricultural areas of Senegal and can be submitted to some pesticide pollution; as river effluents can transfer the pesticide residue to sea water and induce fish contamination, studies have been also carried out on sea water samples from Dakar seaside. From France (Brittany district), we have taken samples from Penfeld River and from tap water of Brest city.

In order to get a matrix free of organic contaminants, the water samples were first filtered at $45 \mu \mathrm{m}$ in order to eliminate the suspended organic matter, and then purified by solid phase extraction in order to eliminate the dissolved organic matter. The samples were then by analysed by AUTOPIF and AUTOPIF+ using the standard addition method. They were initially fortified at $0.40 \mu \mathrm{g} \cdot \mathrm{mL}^{-1}$ for MLN and FLM and at $0.23 \mu \mathrm{g} \cdot \mathrm{mL}^{-1}$ for DFB. Increasing concentrations were added on those and the standard addition curves obtained were compared to the calibration curves (Figure 5 and 6).

Thus, in a first time, the linearity of the standard addition curves has been also tested by variance analysis (as explain in paragraph 3.3). In all cases, the regression is significant, without lack fit (at $5 \%$ confidence level), meaning that the linear model is validated.

Then parallelism between the standard addition curves and the reference calibration curves was evaluated by a student $t$ test. For each pesticide, the tabulated Student $t$ value (confidence level of $5 \%$ ) is higher than the calculated $t$ of the difference; showing no significant differences between the slopes of the standard addition curves and the slope of the reference calibration curve (Table 6 and 7 for AUTOPIF and AUTOPIF+ respectively). This indicates the absence of significant matrix effects. 
Figure 5. Standard addition curves and the reference calibration of MLN.

AUTOPIF

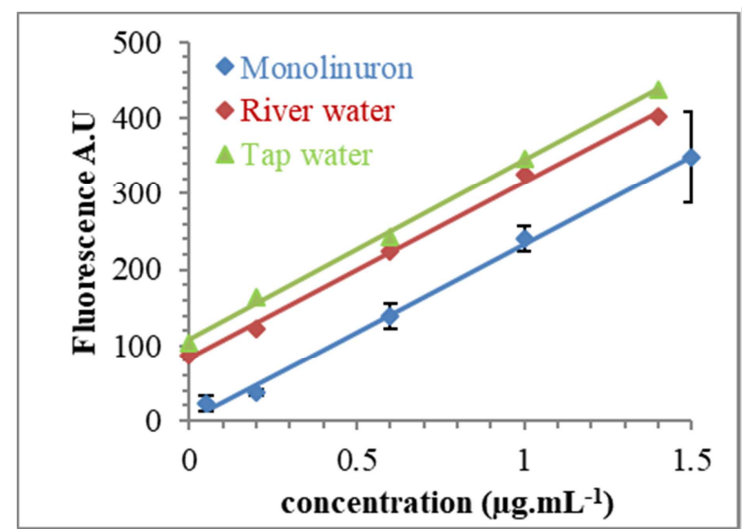

AUTOPIF +

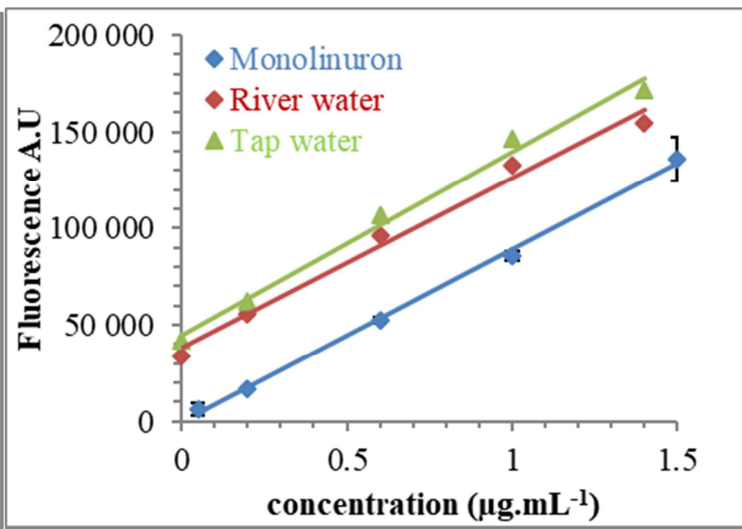

Figure 6. Standard addition curves and the reference calibration of FLM.

AUTOPIF

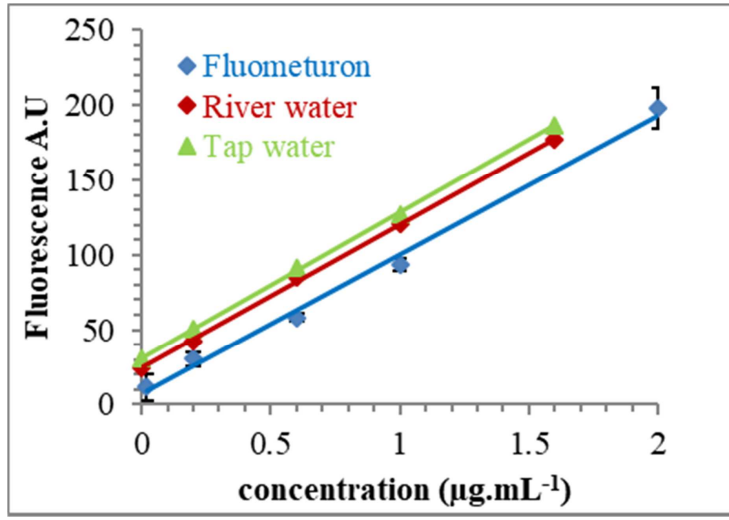

AUTOPIF +

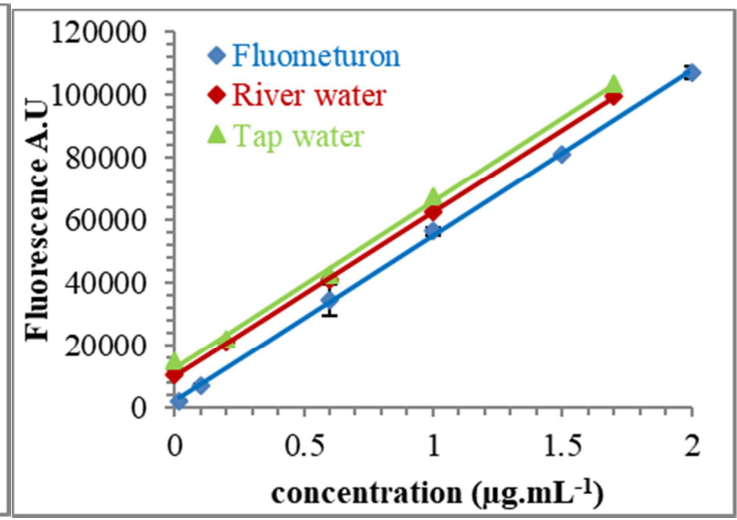

Table 6: Comparison of the addition standard curve and calibration curve slopes obtained by AUTOPIF method by a Student difference $t$ test.

\begin{tabular}{|c|c|c|c|c|c|c|}
\hline \multicolumn{7}{|c|}{ AUTOPIF } \\
\hline & MLN & River water & Tap water & FLM & River water & Tap water \\
\hline Slope & 232,16 & 236,05 & 231,34 & 98,52 & 96,16 & 96,44 \\
\hline STD & 7,76 & 6,01 & 6,03 & 5,4 & 3,26 & 5,57 \\
\hline d.o.f & & 8 & 8 & & 8 & 8 \\
\hline$t_{\mathrm{D}}$ & & 0,88621 & 0,186577 & & 0,83661 & 0,599521 \\
\hline$t_{\mathrm{S}}(5 \%)$ & & 2,306 & 2,306 & & 2,306 & 2,306 \\
\hline SD & & $\mathrm{NO}$ & $\mathrm{NO}$ & & $\mathrm{NO}$ & $\mathrm{NO}$ \\
\hline
\end{tabular}

STD: Standard Deviation of the slope of the standard addition curve; d.o.f.: degrees of freedom; $t_{\mathrm{D}}$ :

Calculated Student value of the difference between the two slopes; $t$ Tabulated Student $t$ value; SD significant difference 
Table 7: Comparison of the addition standard curve and calibration curve slopes obtained by AUTOPIF+ method by a Student difference $t$ test.

\begin{tabular}{|c|c|c|c|c|c|c|c|c|c|}
\hline \multicolumn{10}{|c|}{ AUTOPIF+ } \\
\hline & MLN & $\begin{array}{l}\text { River } \\
\text { water }\end{array}$ & $\begin{array}{c}\text { Tap } \\
\text { water }\end{array}$ & FLM & $\begin{array}{l}\text { River } \\
\text { water }\end{array}$ & $\begin{array}{c}\text { Tap } \\
\text { water }\end{array}$ & DFB & Sea water & $\begin{array}{c}\text { Tap } \\
\text { water }\end{array}$ \\
\hline Slope & $8.91110^{4}$ & $8.78710^{4}$ & $9.46510^{4}$ & $\begin{array}{r}5.266 \\
10^{4}\end{array}$ & $\begin{array}{r}5.320 \\
10^{4}\end{array}$ & $\begin{array}{r}5.176 \\
10^{4}\end{array}$ & $\begin{array}{r}1.728 \\
10^{4}\end{array}$ & $1.76610^{4}$ & $\begin{array}{r}1.709 \\
10^{4}\end{array}$ \\
\hline STD & $2.22810^{3}$ & $5.80310^{3}$ & $5.56410^{3}$ & $\begin{array}{r}1.130 \\
10^{3} \\
\end{array}$ & $\begin{array}{r}1.60 \\
10^{3} \\
\end{array}$ & $\begin{array}{r}2.084 \\
10^{3} \\
\end{array}$ & $\begin{array}{r}3.07 \\
10^{2} \\
\end{array}$ & $5.4410^{2}$ & $\begin{array}{r}4.76 \\
10^{2}\end{array}$ \\
\hline d.o.f & & 8 & 8 & & 9 & 9 & & 10 & 12 \\
\hline$t_{\mathrm{D}}$ & & 0.445 & 2.066 & & 0.651 & 0.599 & & 1.575 & 0.875 \\
\hline$t_{\mathrm{S}}(5 \%)$ & & 2.306 & 2.306 & & 2.262 & 2.262 & & 2.28 & 2.179 \\
\hline SD & & $\mathrm{NO}$ & $\mathrm{NO}$ & & $\mathrm{NO}$ & $\mathrm{NO}$ & & $\mathrm{NO}$ & $\mathrm{NO}$ \\
\hline
\end{tabular}

STD: Standard Deviation of the slope of the standard addition curve; d.o.f.: degrees of freedom; $t_{\mathrm{D}}$ : Calculated Student value of the difference between the two slopes; $t$ Tabulated Student $t$ value; SD significant difference

\subsection{Method validation for applications}

To validate the method a recovery study has been performed by spiking each water sample with an appropriate amount of MLN, FLM and DFB. The recoveries obtained can be observed in Table 8 for AUTOPIF and in Table 9 for AUTOPIF+. The recovery values were very close to $100 \%$, ranging from $98 \%$ to $108 \%$ for AUTOPIF and $99 \%$ to $105 \%$ for AUTOPIF+. The relative standard deviation of the concentration found ranged from $3.5 \%$ to 7.6\% for AUTOPIF and $2.3 \%$ to $5.1 \%$ for AUTOPIF+. The developed methods (AUTOPIF and AUTOPIF+) are then suitable to determine the benzoyl- and phenylurea pesticides in river, sea water and tap water samples, but the detection by AUTOPIF+ give the better results.

In order to show the practical interest of the method in these samples of sea and river water we have also done triplicates test points, at concentrations different from theses of the calibration curves. The predicted concentration values obtained by reference to the calibrations curves are found to be not different to the real value by a Student $t$ test (Table 10 and 11). 
Table 8: Recovery values obtained in spiked river water and tap water samples for the determination of MLN and FLM by AUTOPIF.

\begin{tabular}{|c|c|c|c|c|c|}
\hline & $\begin{array}{c}\text { Added } \\
\left(\mu \mathrm{g} \mathrm{mL} L^{-1}\right)\end{array}$ & $\begin{array}{c}\text { Found } \\
\left(\mu \mathrm{gL} \mathrm{m}^{-1}\right)\end{array}$ & $\begin{array}{c}\text { Recovery, } \\
\mathrm{R}(\%)\end{array}$ & $\begin{array}{c}\text { Mean recovery, } \\
\mathrm{Rm}(\%)\end{array}$ & $\begin{array}{c}\text { Relative standard } \\
\text { deviation, } \mathrm{s}(\mathrm{R})(\%)\end{array}$ \\
\hline \multicolumn{6}{|c|}{ River water } \\
\hline \multirow{5}{*}{ MLN } & 0.4 & $0.43 \pm 0.08$ & $107.50 \pm 21.25$ & & \\
\hline & 0.6 & $0.69 \pm 0.08$ & $115.00 \pm 13.50$ & & \\
\hline & 1.0 & $1.04 \pm 0.09$ & $104.00 \pm 9.30$ & 105.79 & 6.06 \\
\hline & 1.4 & $1.38 \pm 0.13$ & $98.00 \pm 9.29$ & & \\
\hline & 1.8 & $1.87 \pm 0.17$ & $103.89 \pm 9.44$ & & \\
\hline \multirow{5}{*}{ FLM } & 0.2 & $0.19 \pm 0.11$ & $95.00 \pm 55,00$ & & \\
\hline & 0.4 & $0.39 \pm 0.15$ & $97.50 \pm 37.50$ & & \\
\hline & 0.8 & $0.78 \pm 0.13$ & $97.50 \pm 16.25$ & 98.36 & 2.81 \\
\hline & 1.2 & $1.19 \pm 0.14$ & $99.17 \pm 11.67$ & & \\
\hline & 1.9 & $1.95 \pm 0.23$ & $102.63 \pm 12.11$ & & \\
\hline \multicolumn{6}{|c|}{ Tap water } \\
\hline \multirow{5}{*}{ MLN } & 0.4 & $0.43 \pm 0.08$ & $107.50 \pm 22.25$ & & \\
\hline & 0.6 & $0.61 \pm 0.08$ & $101.67 \pm 13.67$ & & \\
\hline & 1.0 & $0.95 \pm 0.08$ & $95.00 \pm 8.80$ & 100.33 & 4.66 \\
\hline & 1.4 & $1.38 \pm 0.12$ & $98.57 \pm 8.57$ & & \\
\hline & 1.8 & $1.78 \pm 0.15$ & $98.89 \pm 98.89$ & & \\
\hline \multirow{5}{*}{ FLM } & 0.2 & $0.20 \pm 0.10$ & $100.00 \pm 50.00$ & & \\
\hline & 0.4 & $0.42 \pm 0.16$ & $105.00 \pm 40.00$ & & \\
\hline & 0.8 & $0.85 \pm 0.15$ & $106.25 \pm 18.75$ & 100.76 & 4.94 \\
\hline & 1.2 & $1.18 \pm 0.17$ & $98.33 \pm 14.17$ & & \\
\hline & 1.9 & $1.79 \pm 0.22$ & $94.21 \pm 11.58$ & & \\
\hline
\end{tabular}


Table 9: Recovery values obtained in spiked river tap water and sea water samples for the determination of MLN, FLM and DFB "AUTOPIF+"

\begin{tabular}{|c|c|c|c|c|c|}
\hline & $\begin{array}{l}\text { Added } \\
\left(\mu \mathrm{g} \mathrm{mL}^{-1}\right)\end{array}$ & $\begin{array}{l}\text { Found } \\
(\mu \mathrm{g} \mathrm{mL})\end{array}$ & $\begin{array}{l}\text { Recovery, } \\
\mathrm{R}(\%)\end{array}$ & $\begin{array}{l}\text { Mean recovery, } \\
\operatorname{Rm}(\%)\end{array}$ & $\begin{array}{l}\text { Relative standard } \\
\text { deviation, } \mathrm{s}(\mathrm{R})(\%)\end{array}$ \\
\hline \multicolumn{6}{|c|}{ River water } \\
\hline \multirow{5}{*}{ MLN } & 0.4 & $0.41 \pm 0.06$ & $102.50 \pm 16.25$ & & \\
\hline & 0.6 & $0.62 \pm 0.06$ & $103.33 \pm 10.17$ & & \\
\hline & 1.0 & $1.07 \pm 0.06$ & $107.00 \pm 6.90$ & 102.93 & 4.22 \\
\hline & 1.4 & $1.48 \pm 0.08$ & $105.71 \pm 5.93$ & & \\
\hline & 1.8 & $1.73 \pm 0.11$ & $96.11 \pm 6.11$ & & \\
\hline \multirow{5}{*}{ FLM } & 0.2 & $0.21 \pm 0.09$ & $105.00 \pm 46.00$ & & \\
\hline & 0.4 & $0.39 \pm 0.08$ & $97.50 \pm 22.25$ & 100.20 & 3.98 \\
\hline & 0.8 & $0.76 \pm 0.07$ & $95.00 \pm 9.50$ & & \\
\hline & 1.2 & $1.23 \pm 0.07$ & $102.50 \pm 6.00$ & & \\
\hline & 1.9 & $1.92 \pm 0.11$ & $101.05 \pm 5.79$ & & \\
\hline \multicolumn{6}{|c|}{ Sea water } \\
\hline \multirow{5}{*}{ DFB } & 0.2 & $0.20 \pm 0.02$ & $100.00 \pm 14.50$ & & \\
\hline & 0.3 & $0.35 \pm 0.02$ & $116.67 \pm 8.67$ & & \\
\hline & 0.4 & $0.43 \pm 0.02$ & $107.50 \pm 5.75$ & 105.52 & 9.99 \\
\hline & 0.5 & $0.56 \pm 0.02$ & $112.00 \pm 5.20$ & & \\
\hline & 0.7 & $0.64 \pm 0.02$ & $91.43 \pm 3.86$ & & \\
\hline \multicolumn{6}{|c|}{ Tap water } \\
\hline \multirow{5}{*}{ MLN } & 0.4 & $0.42 \pm 0.06$ & $97.50 \pm 16.25$ & & \\
\hline & 0.6 & $0.65 \pm 0.06$ & $108.33 \pm 10.00$ & & \\
\hline & 1.0 & $1.09 \pm 0.06$ & $102.00 \pm 6.90$ & 98.27 & 7.12 \\
\hline & 1.4 & $1.38 \pm 0.08$ & $90.71 \pm 5.93$ & & \\
\hline & 1.8 & $1.91 \pm 0.11$ & $92.78 \pm 6.11$ & & \\
\hline \multirow{5}{*}{ FLM } & 0.2 & $0.17 \pm 0.09$ & $85.00 \pm 46.50$ & & \\
\hline & 0.4 & $0.39 \pm 0.08$ & $97.50 \pm 21.50$ & & \\
\hline & 0.8 & $0.86 \pm 0.07$ & $107.50 \pm 9.25$ & 97.89 & 8.38 \\
\hline & 1.2 & $1.23 \pm 0.07$ & $102.50 \pm 6.00$ & & \\
\hline & 1.9 & $1.84 \pm 0.08$ & $96.84 \pm 4.53$ & & \\
\hline \multirow{5}{*}{ DFB } & 0.2 & $0.20 \pm 0.03$ & $100.00 \pm 19.50$ & & \\
\hline & 0.3 & $0.35 \pm 0.02$ & $116.67 \pm 7.67$ & & \\
\hline & 0.4 & $0.43 \pm 0.02$ & $107.50 \pm 6.25$ & 108.09 & 6.50 \\
\hline & 0.5 & $0.56 \pm 0.02$ & $112.00 \pm 4.60$ & & \\
\hline & 0.7 & $0.73 \pm 0.02$ & $104.29 \pm 3.57$ & & \\
\hline
\end{tabular}

Table 10: Test points: Comparison of the concentration of each test point, to the concentrations found by regression, by a Student $\boldsymbol{t}$ test (AUTOPIF).

\begin{tabular}{|c|c|c|c|c|c|c|c|c|c|c|}
\hline \multirow[b]{2}{*}{ Pesticides } & \multicolumn{5}{|c|}{ Sea water } & \multicolumn{5}{|c|}{ River water } \\
\hline & $\begin{array}{c}\text { Added } \\
\left(\mu \mathrm{g} \mathrm{mL}^{-1}\right)\end{array}$ & $\begin{array}{l}\text { Found } \\
\left(\mu \mathrm{g} \mathrm{mL}^{-1}\right)\end{array}$ & $t_{\mathrm{D}}$ & $\begin{array}{c}t_{\mathrm{S}} \\
(5 \%)\end{array}$ & $\begin{array}{l}\mathrm{S} \\
\mathrm{D}\end{array}$ & $\begin{array}{l}\text { Added } \\
\left(\mu \mathrm{g} \mathrm{mL}^{-1}\right)\end{array}$ & $\begin{array}{l}\text { Found } \\
\left(\mu \mathrm{g} \mathrm{mL}^{-1}\right)\end{array}$ & $t_{\mathrm{D}}$ & $\begin{array}{c}t \\
(5 \%)\end{array}$ & SD \\
\hline MLN & 0.40 & $0.41 \pm 0.01$ & 1.88 & 2.43 & no & 0.40 & $0.41 \pm 0,01$ & $\begin{array}{c}1.2 \\
5\end{array}$ & 2.68 & no \\
\hline FLM & 0.30 & $0,32 \pm 0.02$ & 2.56 & 2.89 & no & 0.3 & $0.32 \pm 0,02$ & $\begin{array}{c}1.3 \\
1\end{array}$ & 2.89 & no \\
\hline
\end{tabular}

$t_{\mathrm{D}}$ : Calculated Student value of the difference between the two slopes; $t$ Tabulated Student $t$ value; SD significant difference 
Table 11: Test points: Comparison of the concentration of each test point, to the concentrations found by regression, by a Student $\boldsymbol{t}$ test(AUTOPIF+).

\begin{tabular}{|c|c|c|c|c|c|c|c|c|c|c|}
\hline \multirow{2}{*}{ Pesticides } & \multicolumn{5}{|c|}{ Sea water } & \multicolumn{5}{|c|}{ River water } \\
\hline & $\begin{array}{l}\text { Added } \\
\left(\mu \mathrm{g} \mathrm{mL}^{-1}\right)\end{array}$ & $\begin{array}{l}\text { Found } \\
\left(\mu \mathrm{g} \mathrm{mL}^{-1}\right)\end{array}$ & $t_{\mathrm{D}}$ & $t_{\mathrm{S}}(5 \%)$ & SD & $\begin{array}{l}\text { Added } \\
\left(\mu \mathrm{g} \mathrm{mL}^{-1}\right)\end{array}$ & $\begin{array}{c}\text { Found } \\
\left(\mu \mathrm{g} \mathrm{mL}^{-1}\right)\end{array}$ & $t_{\mathrm{D}}$ & $t(5 \%)$ & SD \\
\hline MLN & 0.40 & $0.41 \pm 0.02$ & 1.772 & 2.300 & no & 0.40 & $0.41 \pm 0,02$ & 1.309 & 2.230 & no \\
\hline FLM & 0.30 & $0,32 \pm 0.02$ & 2.566 & 2.716 & no & 0.30 & $0.32 \pm 0,02$ & 1.520 & 2.743 & no \\
\hline DFB & 0.30 & $0.31 \pm 0.05$ & 0.779 & 2.320 & no & 0.30 & $0.31 \pm 0.05$ & 0.251 & 2.352 & no \\
\hline
\end{tabular}

\section{Conclusion}

In this present paper, we have associated, for the first time, the photo induced fluorescence method for the determination of pesticides in water, to new automatic on-site alert systems for environments waters, namely "AUTOPIF" and "AUTOPIF+". Thanks to the sensitivity of the fluorescence detection, we have reach the objective to develop a screening method while avoiding any pre-concentration step using complex fluidic systems as in some other commercial apparatus ${ }^{[18,19]}$, in order to keep moderate cost.

We have use these prototypes for the determination of benzoyl- and phenylurea pesticides i.e.: fluometuron, monolinuron and diflubenzuron. In future works, we will investigate in the identification of photoproducts responsible for the observed fluorescence.

We obtained good analytical figures of merit, showing the ability of the methods for detection and quantification of these pesticides in the $\mathrm{ng} \mathrm{mL}^{-1}$ range in aquatic environments which is a sufficient value for an alert system. The analytical applications in spiked natural waters of Senegal and Brest (France) have also led to satisfactory recovery values without significant matrix effects. AUTOPIF+ method gave better results with higher sensitivity thanks to the use of the ICCD camera detection. AUTOPIF is less sensitive but still at a sufficient level for an automatic alert system. In view of its analytical usefulness, AUTOPIF can be apply for the monitoring of pesticides in natural waters at a reasonable cost.

At this time, we are working on new evolutions of the prototypes while using other excitation wavelengths to increase sensitivity and specificity. We are also looking for an industrial partner in order to transform the prototypes into commercial systems and then to apply quality assurance protocol for its certification.

\section{References}

[1] M. D. Gil-García, M. Martínez-Galera, P. Parrilla-Vázquez, A. R. Mughari,I. M. OrtizRodríguez, Application of the Doehlert Design to Optimize the Signal Obtained in Photochemically Induced Fluorescence for the Determination of Eight Phenylureas, J. Fluoresc. 18 ( 2008) 365-73. https://doi.org/10.1007/s10895-007-0276-Z. 
[2] M.E. Leon-Gonzalez, A. Townshend, Determination of organophosphorus and carbamate pesticide standards by liquid chromatography with detection by inhibition of immobilized acetylcholinesterase, J. Chromatogr. 539 (1991)47-54. https://doi.org/10.1016/S00219673(01)95359-2.

[3] M. Weselak, T. E. Arbuckle, D. T. Wigle, D Krewski, In utero pesticide exposure and childhood morbidity, Environ. Res. 103 (2007) 79-86.

https://doi.org/10.1016/j.envres.2006.09.001

[4] N. Rhalem, A. Khattabi, S. Achour, A. Soulaymani, R. S. Bencheikh, Risk Factors for acute pesticide poisoning. Poison Control Centre of Morocco experience, Ann. Toxicol. Anal. 21 (2009) 79-84.https://doi.org/10.1051/ata/2009039.

[5] G. Ding, Y. Bao, Revisiting pesticide exposure and children's health: Focus on China, Sci.Tot. Environ. 472 (2014) 289-295.https://doi.org/10.1016/j.scitotenv.2013.11.067.

[6] G. N. Piccirilli, G. M. Escandar, F. C. Cañada, I. D. Merás, A. M. de la Peña, Flowthrough photochemically induced fluorescence optosensor for the determination of linuron, Talanta. 77(2008) 852-857. https://doi.org/10.1016/j.talanta.2008.07.052.

[7] A.Muñoz de la Peña, M.C.Mahedero, A.Bautista-Sánchez, Monitoring of phenylurea and propanil herbicides in river water by solid-phase-extraction high performance liquid chromatography with photoinduced-fluorimetric detection, Talanta 60 (2003) 279-285. https://doi.org/10.1016/S0039-9140(03)00072-9

[8] O.M.A. Mbaye, M.D. Gaye Seye, A. Coly, A. Tine, M.A. Oturan, N. Oturan, J.J. Aaron. Photo-induced fluorescence properties of the propanil herbicide and analytical usefulness, Microchem. J. 110 2013) 579-58. https://doi.org/10.1016/j.microc.2013.06.010.

[9] D. D. Thiare, A. Coly, D. Sarr, A. Khonte, A. Diop, D. Mame Gaye-Seye, F. Delattre, A. Tine, J. J. Aaron, Determination of the fenvalerate insecticide in natural waters by a photochemically-induced fluorescence method, Maced. J. Chem. Chem. Engin. 34 (2015) 245-254. https://doi.org/10.20450/mjcce.2015.726

[10] J. L. Vilchez, R. El-Khattabi, R. Blanc, A. Navalo, Photochemical-fluorimetric method for the determination of the insecticide imidacloprid in water samples, Anal. Chim. Act. 371 (1998) 247-253. https://doi.org/10.1016/S0003-2670(98)00351-1

[11] E. J. Llorent-Martínez, M. L. Fernández-de Córdova, A. Ruiz-Medina, P. OrtegaBarrales, Reagentless photochemically-induced fluorimetric determination of fipronil by sequential-injection analysis, Anal. Lett. 44 (2011) 2606-2616.

https://doi.org/10.1080/00032719.2011.553006-

[12] U. Tamrakar, V. K. Gupta, A. K. Pillai, A spectro-photometric method for the determination of fenvalerate and cypermethrin in presence of each other, J. Anal. Chem. 67 (2012) 437-442.https://doi.org/10.1134/S1061934812050127.

[13] A.Muñoz de la Peña, M.C.Mahedero, A.Bautista-Sánchez, High-performance liquid chromatographic determination of phenylureas by photochemically-induced fluorescence detection, J. Chromatogr. A 950 (2002) 287. https://doi.org/10.1016/S0021-9673(02)00042-0

[14] Atanasse Coly 1, Jean-Jacques Aaron, Fluorimetric Analysis of Pesticides: Methods, Recent Developments and Applications, Talanta . 46 (1998) 815-843 https://doi.org/ $\underline{10.1016 / \mathrm{S} 0039-9140(97) 00366-4}$

[15] P. Parrilla Vázquez, A. P Mughari, M. Martínez Galera, Application of solid-phase microextraction for determination of pyrethroids in groundwater using liquid chromatography 
with post-column photochemically-induced fluorimetry derivatization and fluorescence detection, J. Chromatogr. A. 1188 (2008) 61- 68.

https://doi.org/10.1016/j.chroma.2008.02.030

[16] M. M. Mbaye, D. Gaye Seye, A. Coly, A. Tine, J. J. Aaron, Usefulness of cyclodextrin media for the determination of $\alpha$-cypermethrin by photochemically-induced fluorescence Analytical applications to natural waters, Anal. Bioanal. Chem. 394 (2009) 1089-1098. https://doi.org/10.1007/s00216-009-2611-5

[17] J. F. Nie, B. Li, Y. Zhang, J. L. Fan, Z. S. Yi, Z. R. Cai, High-order calibration for the spectrofluorimetric determination of pesticides based on photochemical derivatization. A solution of the problems of inner-filter effects and matrix interferences in complex environmental water, Chem. Int. Lab. Syst. 156 (2016) 36-53

https://doi.org/10.1016/j.chemolab.2016.05.004

[18] P. A. Diaw, O. M. A Mbaye, M. D. Gaye-Seye, J. J Aaron, A. Coly, A. Tine, N. Oturan, M. A. Oturan, Photochemically-Induced Fluorescence Properties of Two Benzoyl- and Phenylurea Pesticides and Determination in Natural Waters, J. Fluoresc. 24 (2014) 13191330. https://doi.org/10.1007/s10895-014-1418-8

[19] P. A. Diaw, A. Maroto, O. M. A Mbaye, M. D. Gaye-Seye, L. Stephan, A. Coly, L. Deschamps, A. Tine, J. J. Aaron, P. Giamarchi, Determination of phenylurea pesticides by direct laser photo-induced fluorescence, Talanta. 116 (2013) 569-

574.https://doi.org/10.1016/j.talanta.2013.07.014

[20] M. Mbaye , P.A. Diaw , M. D. Gaye-Seye, B. Le Jeune, G. Cavalin , L. Denis, J.J. Aaron, R. Delmas , P. Giamarchi, Development of online automatic detector of hydrocarbons and suspended organic matter by simultaneously acquisition of fluorescence and scattering, Spectrochim.Acta. A. Mol. Biomol. Spectrosc.192 (2018) 117-121.

https://doi.org/10.1016/j.saa.2017.11.004

[21] B. Roig, I. Delpla, E. Baurès, A.V. Jung, O. Thomas, Analytical issues in monitoring drinking-water contamination related to short-term, heavy rainfall events .Trends. Anal. Chem. 30 (2011) 1243-1251.https://doi.org/10.1016/j.trac.2011.04.008

[22] R. Greenwood, G.A. Mills, B. Roig, Introduction to emerging tools and their use in water monitoring Trends. Anal. Chem. 26 (2007) 263-267.

https://doi.org/10.1016/j.trac.2006.12.006

[23] A. Mansy, E. El-Bestawy, Toxicity and biodegradation of fluometuron by selected cyanobacterial species, W. J. Microbiol.Biotechnol. 18 (2002) 125-131. https://doi.org/10.1023/A:1014490811121.

[24 ] D. Freitag, I. Scheunert, Fate of $\left[{ }^{14} \mathrm{C}\right]$ monolinuron in potatoes and soil under outdoor conditions, Ecotoxicol. Environ. safety. 20 (1990) 256-268. https://doi.org/10.1016/0147$\underline{6513(90) 90005-\mathrm{P}}$

[25] Tomlin CDS (ed) (2000) The pesticide manual, 12th edn. British Crop Protection Council, Surrey.

[26] J. A. M. Pulgarín, L. F. García, B. S. B. Rodríguez, Direct Determination of Dichlorprop in Commercial Formulations, Tomato and Fruit Samples Using Photochemically Induced Fluorescence, Food. Anal. Met, 8 (2015) 1718-1726.https://doi.org/10.1007/s12161-014$\underline{0036-Z}$

[27] M. D. Gil-García, M. Martínez-Galera, D. Barranco-Martínez, J. G. Gallego, Determination of benzoylureas in ground water samples by fully automated on-line pre- 
concentration and liquid chromatography-fluorescence detection, J. Chromatogr A, 1103: (2006) 271-277. https://doi.org/10.1016/j.chroma.2005.11.037

[28] O.M.A. Mbaye, A. Maroto, M.D. Gaye-Seye, L. Stephan, L. Deschamps, J.J. Aaron, P. Giamarchi, A new direct laser photo-induced fluorescence method coupled on-line with liquid chromatographic separation for the simultaneous determination of anilides pesticides, Talanta, 132 (2015) 909-914. https://doi.org/10.1016/j.talanta.2014.08.052

[29] S. Irace-Guigand, E. Leverend, M.D. Seye, J.J. Aaron, A new on-line micellar-enhanced photochemically induced fluorescence method for determination of phenylurea herbicide residues in water, Lumines. 20 (2005) 138-180. https://doi.org/10.1002/bio.817.

[30] M. D. Gil-Garcia, M. Martínez-Galera, T. López-López, J. L. Martínez-Vidal, M. C. Mahedero, Salinas F. Photochemical-spectrofluorimetric method for the determination of benzoylurea insecticides: Applications in river water samples and in technical formulations, Talanta, 53 (2001) 915-925.https://doi.org/ 10.1016/S0039-9140(00)00528-2. 


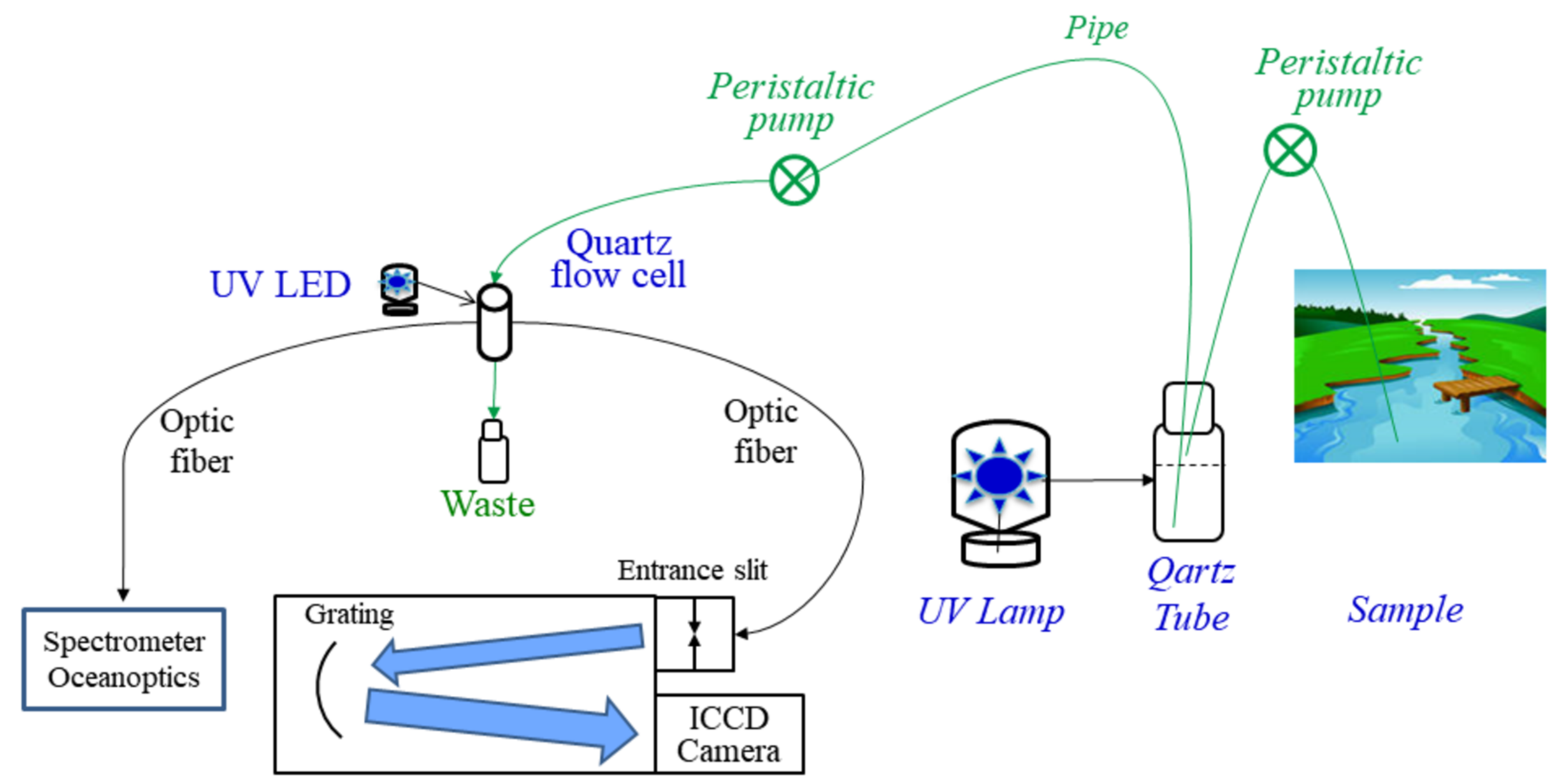

